\title{
Evaluation of antibacterial and antioxidant activity of Aloe vera (Aloe barbadensis Miller) gel powder using different solvents
}

\author{
Faiza Iftikhar Gorsi, Tusneem Kausar* and Mian Anjum Murtaza \\ Institute of Food Science and Nutrition, University of Sargodha, Sargodha 40100-Pakistan \\ *Corresponding author's email:tusneem.kausar@uos.edu.pk
}

\section{Citation}

Faiza Iftikhar Gorsi, Tusneem Kausar and Mian Anjum Murtaza. Evaluation of antibacterial and antioxidant activity of Aloe vera (Aloe barbadensis Miller) gel powder using different solvents. Pure and Applied Biology. Vol. 8, Issue 2, pp1265-1270. http://dx.doi.org/10.19045/bspab.2019.80068

Received: 07/12/2018 Revised: 04/04/2019

Accepted: 10/04/2019

Online First: 18/04/2019

\section{Abstract}

The present study was planned to investigate the phytochemical compounds present in Aloe vera and antimicrobial and antioxidant activity of Aloe vera gel powder with different solvents. The phytochemical compounds were screened qualitatively and glycosides, flavonoids, tannins, phenols, saponins, proteins, triterpeniods gave positive results while alkaloids and phlobatannin gave negative results. The polyphenol and flavonoid contents and antioxidant activity of Aloe vera gel powder extract using three different solvents (ethanol, methanol, acetone) were analyzed. The ethanolic extract showed maximum polyphenol (28.44 $\pm 2.67 \mathrm{mg} \mathrm{GAE} / \mathrm{g})$, flavonoid (63.90 2.39 $\mathrm{mg} \mathrm{CE} / \mathrm{g}$ ) and DPPH radical scavenging activity (51.09 $\pm 0.33 \%)$. Antibacterial activity of extracts was examined by agar diffusion method with four microbial species (Salmonella typhi, Escherchia coli, Bacillus subtilis and Staphylococcus aureus). Maximum antibacterial activity was observed in ethanol extract of Aloe vera gel powder. Hence, Aloe vera gel powder can be used as an antimicrobial and antioxidant agent in food preservation and to prevent diseases related to oxidative stress.

Keywords: Aloe vera gel powder; Antibacterial activity; Antioxidant capacity; Phytochemicals; Solvents; Total polyphenols

\section{Introduction}

Aloe vera has been used in ancient cultures of India, Egypt, Greece, Rome and China for its medicinal value for several thousand years. It was known as plant of immortality in biblical times by the Egyptians and believed to be effective for wound healing, for antiinflammatory effect, for radiation injury, to treat gastrointestinal problems, skin diseases and as an anti-ulcer and anti-diabetes. The
Aloe vera is derived from the Arabic word "Alloeh" which mean bitter substance and also known as first aid plant or burn plant [1]. In the food industry, it has been considered as an important ingredient in functional foods and health drinks, beverages and curd $[2,3]$. Aloe vera is considered as curative agent mainly due to presence of transparent and soft tissue inside the leaf. The polysaccharides present in Aloe vera extracts 
are responsible for health benefits $[4,5]$. Aloe vera gel has many biological activities including its antimicrobial activity, antidiabetic effects, antioxidant activity, antiinflammatory and protection of gastrointestinal tract $[2,4,6-8]$. Antioxidant effect of Aloe vera gel has been reported by several researchers. In Aloe vera gel, compounds like phenolic antioxidants, glutathione peroxidase activity and superoxide dismutase enzymes are responsible for its antioxidant effects [2]. Anthraquinones responsible for antimicrobial activity were [9] isolated from the exudates of Aloe vera. Due to its important constituents, Aloe vera has been used as main and important ingredient for soaps, shampoos, creams, lotions and other products in the toiletry and cosmetic industry. In the pharmaceutical industry, it has been utilized in production of ointments and gel production as well as in manufacturing of tablets and capsules $[10,11]$. The present study was planned to screen phytochemical compounds (qualitative method) and to analyze antibacterial activity and antioxidant capacity of Aloe vera gel powder (extracts of ethanol, methanol and acetone).

\section{Materials and methods}

\section{Procurement of raw materials}

Aloe vera leaves (Aloe barbadensis Miller) were purchased from local nurseries of Sargodha and selected on the basis of size, maturity, color, freshness for the present study. Other chemicals, required for this study were purchased from Scientific Store, Faisalabad.

\section{Preparation of extract}

Aloe vera gel was separated from leaves by using sharp knife. Aloe vera rind and gel were dried in conventional oven at $50 \pm 5^{\circ} \mathrm{C}$ [12]. The dried samples were crushed, powdered and packed in air tight container for further studies. For preparation of extract, $0.5 \mathrm{~g}$ powdered material was mixed with $50 \mathrm{ml}$ of $80 \%$ aqueous solution of solvents (methanol, ethanol, acetone) and placed in an ultrasonic bath for $20 \mathrm{~min}$.

\section{Phytochemical Screening}

Analysis of phytochemical constituents of Aloe vera gel powder was done qualitatively $[13,14]$.

\section{Total phenolic assay}

The reagent Folin-Ciocaltue was used to measure total phenolic content of the extracts [15]. In, $0.5 \mathrm{ml}$ of extracts, $2.5 \mathrm{ml}$ of FolinCiocalteu's phenolic reagent was added. After $5 \mathrm{~min}$ at room temperature $2.5 \mathrm{ml}$ of $7.5 \%$ sodium carbonate solution was added and allowed to incubate for $90 \mathrm{~min}$ at room temperature and absorbance was determined at $765 \mathrm{~nm}$ with UV-VIS spectrophotometer. Total phenolic content of samples was expressed as milligram of gallic acid equivalents (GAE)/g dry weight.

\section{Total flavonoids assay}

The method used to determine the total flavonoids in Aloe vera sample was Aluminium Chloride $\left(\mathrm{AlCl}_{3}\right)$ colorimetric assay [16]. In $10 \mathrm{ml}$ volumetric flask which have $4 \mathrm{ml}$ of $\mathrm{H}_{2} \mathrm{O}, 1 \mathrm{ml}$ of extract was added and after $5 \min 10 \% \mathrm{AlCl}_{3}$ and after one min, $2 \mathrm{ml}$ of $1 \mathrm{M} \mathrm{NaOH}$ was mixed and total volume was made upto $10 \mathrm{ml}$ with $\mathrm{H}_{2} \mathrm{O}$. The absorbance of mixture was measured using UV-VIS spectrophotometer at $510 \mathrm{~nm}$. Total flavonoid content of samples was expressed as $\mathrm{mg}$ catechin equivalents (CE)/g dry sample.

\section{Antioxidant activity determination}

Antioxidant activity of methanolic, ethanolic and acetone extracts were analyzed by DPPH (2,2-diphenyl-1-picrylhydrozyl) method [17]. In $3 \mathrm{ml}$ of extract, $0.1 \mathrm{mM}$ of DPPH solution was added and kept in dark place for $30 \mathrm{~min}$ at room temperature and absorbance was measured at $517 \mathrm{~nm}$ on a UV-VIS spectrophotometer.

The antioxidant activity was calculated by using the following formula:

Antioxidant activity $(\%)=[(\mathrm{AC}-\mathrm{AE}) / \mathrm{AC}] \mathrm{x}$ 100 
Where

$\mathrm{AC}=$ absorbance of a DPPH solution without extract

$\mathrm{AE}=$ absorbance of the tested extract

\section{Antibacterial activity of Aloe vera}

The antibacterial activity of Aloe vera was determined by disc diffusion technique [18]. The bacterial test organisms i-e gram positive (Bacillus Subtilis, Staphylococcus Aureus) and gram negative (Salmonella Typhi, Eschersia Coli) were inoculated at the nutrient agar medium using sterile cotton buds and incubated at $37^{\circ} \mathrm{C}$ for $24 \mathrm{hrs}$. The diameter of inhibition zones was measured in millimetre.

\section{Results and discussion}

\section{Screening of phytochemical components}

The present studies revealed that Aloe vera gel powder contain important phytochemical compounds. The presences of active phytochemicals were qualitatively analyzed and results are shown in (Table 1). Glycosides, flavonoids, tannins, phenols and spanions were found to be present in the studied sample while phlobatannins and alkaloids were found absent. Presence of mono- and polysaccharides, saponins, tannins, organic acids, sterols, enzymes, various vitamins and minerals in Aloe vera were confirmed in a previous study [19].

Total phenolic, total flavonoid and antioxidant capacity of Aloe vera gel powder

Polyphenols are the group of compounds containing phenolic hydroxyl attached to ring structures, due to which they function as antioxidant. These compounds have many functions such as reducing agents, singlet oxygen quenchers and hydrogen donating antioxidants [20].

Total phenolic and flavonoid contents of Aloe vera gel powder were extracted by using methanol, ethanol and acetone solvents. Results showed that ethanol extract had highest total phenolic content $(28.44 \pm 2.673$ $\mathrm{mg}$ GAE/g) and total flavonoids
(63.90 $\pm 2.396 \mathrm{mgCE} / \mathrm{g}$ ) as compared to methanol $(27.15 \pm 2.244 \quad \mathrm{mgGAE} / \mathrm{g}$, $16.76 \pm 3.048 \mathrm{mgCE} / \mathrm{g})$ and acetone $(11.48 \pm 0.238 \quad \mathrm{mgGAE} / \mathrm{g}, \quad 5.21 \pm 0.478$ $\mathrm{mgCE} / \mathrm{g}$ ) extract, respectively (Table 2).

The Aloe vera gel powder in ethanol solvent showed maximum antioxidant activity 51.09 $\%$ while acetone extract of Aloe vera gel showed minimum antioxidant activity $24.37 \%$ (Table 3). Aloe vera possesses antioxidant properties as showing great amount of polyphenols. As over past many years, the food manufacturers and scientists showed great interest in importance of polyphenols. Antioxidants play a vital role in prevention of many diseases linked with oxidative stress like cancer, cardiovascular disease, nerve degeneration [21] and diabetes [22].

The antioxidant activity observed by Aloe vera gel may be comparable to amount of ascorbic acid, since both functions as scavenger of free radicals which are responsible cellular damage, aging and cardiovascular diseases $[23,24]$. The antioxidant activity of Aloe vera depends upon the maturity. It was [25] reported that at different stages of development, the plant has different active compounds showing different antioxidant activity.

\section{Antibacterial activity of Aloe vera}

Antibacterial activity of Aloe vera gel powder in methanol, ethanol and acetone was analyzed against two gram positive bacteria (Staphylococcus aureus, Bacillus subtilis) and two gram negative (Salmonella typhi, Eschersia coli). The ethanolic extract of Aloe vera gel powder showed antibacterial activity against all test organisms (gram positive and gram negative) with highest activity on Bacillus subtilis, and Staphylococcus aureus i-e $20.33 \pm 0.073 \mathrm{~mm}$ and $18.63 \pm 0.101 \mathrm{~mm}$ of inhibition zone, respectively (Table 4). Acetone extract showed maximum antibacterial activity $(13.60 \pm 0.141 \mathrm{~mm})$ against Salmonella typhi. In a previous study, 
it was observed that acetone exhibit maximum antibacterial activities against Streptococcus pyogenes, Staphylococcus aureus, Escherichia coli and Pseudomonas aeruginosa other than aqueous extract and ethanol extract [26]. Some plant compounds like saponins [27] have been reported to have direct antimicrobial activity. In (Figure 1) compares antibacterial activity of different extracts (ethanol, methanol, and acetone) of Aloe vera gel powder with positive control (ciprofloxacin).

Table 1. Qualitative analysis of phytochemical components of Aloe vera gel powder

\begin{tabular}{|c|c|c|c|}
\hline Components & Tests & Observations & $\begin{array}{c}\text { Aloe vera } \\
\text { gel powder }\end{array}$ \\
\hline Reducing sugars & Fehling's test & Reddish brown ppt & + \\
\hline Alkaloids & Wagner's test & No reddish brown ppt & - \\
\hline Glycosides & Killer-killiani test & Bluish green in upper layer & + \\
\hline Flavonoids & Shinoda test & Pink colour & + \\
\hline Tannins & Ferric chloride test & Blue-black colour & + \\
\hline Phenols & Lead acetate test & White ppt & + \\
\hline Saponins & Foam test & Frothing takes place & + \\
\hline Proteins & Biuret's test / Ninhydrin test & Violet solution / purple solution & + \\
\hline Triterpeniods & Salkowaski test & Greenish blue color & + \\
\hline Phlobatannin & $1 \%$ Hydrochloric acid & Red ppt & - \\
\hline
\end{tabular}

(+) presence (-) absence

Table 2. Total polyphenols and total flavonoid contents of Aloe vera gel powder

\begin{tabular}{|c|c|c|c|}
\hline Compounds & Ethanol Extract & Methanol Extract & Acetone Extract \\
\hline Total polyphenols content (mg GAE/g) & $28.44 \pm 2.673$ & $27.15 \pm 2.244$ & $11.48 \pm 0.238$ \\
\hline Total flavonoids content (mg CE/g) & $63.90 \pm 2.396$ & $16.76 \pm 3.048$ & $5.21 \pm 0.478$ \\
\hline
\end{tabular}

Values are mean \pm standard deviation

Table 3. Antioxidant activity by DPPH radical scavenging of Aloe vera gel extracts measured as percentage inhibition

\begin{tabular}{|c|c|c|c|}
\hline Concentrations & Ethanol extract (\%) & Methanol extract (\%) & Acetone extract (\%) \\
\hline $400 \mu \mathrm{g} / \mathrm{ml}$ & $51.09 \pm 0.338$ & $49.90 \pm 0.665$ & $24.37 \pm 0.624$ \\
\hline $200 \mu \mathrm{g} / \mathrm{ml}$ & $44.94 \pm 1.110$ & $47.95 \pm 0.893$ & $21.60 \pm 1.225$ \\
\hline $100 \mu \mathrm{g} / \mathrm{ml}$ & $40.19 \pm 0.544$ & $43.20 \pm 0.435$ & $19.82 \pm 0.617$ \\
\hline $50 \mu \mathrm{g} / \mathrm{ml}$ & $36.76 \pm 0.637$ & $39.81 \pm 0.737$ & $17.36 \pm 0.765$ \\
\hline $25 \mu \mathrm{g} / \mathrm{ml}$ & $29.14 \pm 0.382$ & $30.97 \pm 0.705$ & $11.29 \pm 0.666$ \\
\hline
\end{tabular}

Values are means \pm standard deviation

Table 4. Antibacterial activity of different Aloe vera gel extracts measured as zone of inhibition (mm)

\begin{tabular}{|c|c|c|c|}
\hline Organisms & Methanol extract & Ethanol extract & Acetone extract \\
\hline Bacillus subtilis & $17.30 \pm 0.024$ & $20.30 \pm 0.073$ & $11.30 \pm 0.106$ \\
\hline Staphylococcus aureus & $11.33 \pm 0.047$ & $18.63 \pm 0.101$ & $10.60 \pm 0.082$ \\
\hline Salmonella typhi & $10.93 \pm 0.262$ & $12.73 \pm 0.227$ & $13.60 \pm 0.141$ \\
\hline Escherchia coli & $14.63 \pm 0.267$ & $12.87 \pm 0.019$ & $10.20 \pm 0.188$ \\
\hline
\end{tabular}

Values are mean \pm standard deviation 


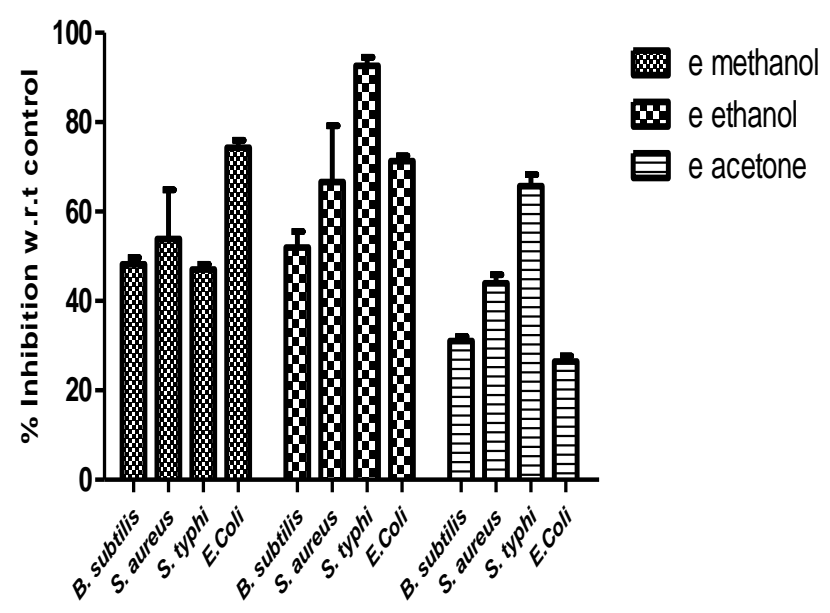

Graph 1. Antibacterial activity of Aloe vera gel powder extract using ethanol, methanol and acetone solvent w.r.t control

\section{Conclusion}

From the present study, it was concluded that Aloe vera gel powder contain some important medicinal compounds and ethanolic extract showed more total polyphenol, total flavonoid, antioxidant capacity and antibacterial activity as compared to methanolic and acetone extract. The ethanolic extract of Aloe gel powder showed highest antibacterial activity on Bacillus subtilis and Staphylococcus aureus while acetone extract showed maximum antibacterial activity against Salmonella typhi. So, Aloe vera gel powder is valuable to be used in food, cosmetics and medicines.

\section{Authors' contributions}

Conceived and designed the experiments: $\mathrm{T}$ Kausar \& FI Gorsi, Performed the experiments: FI Gorsi, Analyzed the data: T Kausar \& FI Gorsi, Contributed reagents/ materials/ analysis tools: T Kausar, FI Gorsi, MA Murtaza, Wrote the paper: T Kausar.

\section{References}

1. Ahlwat SK \& Khatkar SB (2011). Processing, food applications and safety of aloe vera products: a review. J Food Sci Technol 48: 525-533.

2. Hamman JH (2008.) Composition and application of aloe vera leaf gel. Molecules 13: 1599-1616.
3. Ramachandran P \& Srividya N (2014). In vitro antidiabetic activity and in vitro post prandial glycemic response of aloe gel enriched curd. IJFANS 3(1): 38-46.

4. Ni Y \& Tizard IR (2004). Analytical methodology: the gel-analysis of aloe pulp and its derivatives. In Aloes The Genus Aloe; Reynolds T edition, CRC Press: Boca Raton, pp 111-126.

5. Ni Y, Yates KM \& Tizard IR (2004). Aloe polysaccharides. In Aloes The Genus Aloe; Reynolds T edition, CRC Press: Boca Raton, pp 75-87

6. Talmadge J, Chavez J, Jacobs L, Munger C \& Chinnah T (2004). Fractionation of Aloe vera $\mathrm{L}$. inner gel, purification and molecular profiling of activity. Inter $J$ Immunopharma 4: 1757-1773.

7. Reynolds T \& Dweck AC (1999). Aloe vera leaf gel: a review update. J Ethno pharma 68: 3-37.

8. Kar SK \& Bera TK (2018). Phytochemcial constituents of Aloe vera and their multifunctional properties: a comprehensive review. IJPSR 9(4): 1416-1423.

9. Alves DS, Perez-Fons L, Estepa A \& Micol V (2004). Membrane-related effects underlying the biological activity of the anthraquinones emodin and 
barbaloin. Biochem Pharma 68: 549561.

10. Liu RH (2000). Supplement quick fix fails to deliver. Intern J Food Technol 1:71-72.

11. Herraiz $\mathrm{T}$ \& Galisteo J (2004). Endogenous and dietary indoles: a class of Antioxidants and Radical Scavengers in the ABTS Assay. Free Redical Res 38: 323-331.

12. Vega A, Elsa U, Roberto L \& Margarita M (2007). Hot-air drying characteristics of Aloe vera (Aloe barbadensis Miller) and influence of temperature on kinetic parameters. Food Sci Technol 40: 16981707.

13. Sofowara A (1993). Medicinal plants and Traditional medicine in Africa, Spectrum Books Ltd., Ibadan, Nigeria, pp. 289.

14. Harborne BJ (1973). Phytochemcial methods, London, Chapman and Hall Ltd., pp. 49- 188.

15. Singleton VL \& Rossi JA (1965). Colorimetry of total phenolics with phosphomolybdic-phosphotungstic acid reagents. American J Enol Viticulture 16: 144-150.

16. Zhinshen J, Mengcheng T \& Jianming W (1999). The determination of flavonoid content in mulberry and their scavenging effects in superoxide radicals. Food Chem 64: 555-559.

17. Williams BW, Cuvelier EM \& Berset $C$ (1995). Use of a Free Radical Method to Evaluate Antioxidant Activity. Lebensm.-Wiss. U-Technol 28: 25-30.

18. Marinova D, Robarova F \& Atanassova M (2005) Total phenolics and total flavonoids in bulgarian fruits and vegetables. J Univer Chemical Technol Metal 40: 255-260.

19. Newall CA, Anderson LA \& Phillipson JD (1996). Herbel medicines. The pharmaceutical Press London, pp 25.
20. Suresh M, Arularasan S \& Sri KN (2012). Screening on antimicrobial activity of marine gastropods Babylonia Zeylanica (Bruguière, 1789) and Harpa Conoidalis (Lamarck, 1822) from Mudasalodai, Southeast coast of India. Inter J Pharm Pharm Sci 4: 552-556.

21. Normen L, Dutta P, Lia A \& Andersson $\mathrm{H}$ (2000). Soy sterol esters and asitostanol ester as inhibitors of cholesterol absorption in human small bowel. Am J Clin Nutr 71: 908-913.

22. Jones PJ, Ntanios FY, Raeini-Sarjaz M \& Vanstone CA (1999). Cholesterollowering efficacy of a sitostanolcontaining phytosterol mixture with a prudent diet in hyperlipidemic men. Am J Clin Nutr 69: 1144-1150.

23. Kim S, Lee KW, Park J, Lee HJ \& Hwang IK (2006). Effect of drying in antioxidant activity and changes of ascorbic acid and colour by different drying and storage in Korean red pepper (Capsicum annuum L.). Inter J Food Sci Technol 41: 90-95.

24. Venereo JR (2002). Dano oxidativo, radicales libres y antioxidantes. Revista Cubanade Medicina Militar 31: 126133.

25. Hu Q, Xu J \& Hu Y (2003). Evaluation of antioxidant potential of Aloe vera (Aloe barbadensis Miller) extracts. $J$ Agri Food Chem 51: 7788-7791.

26. Simopoulos AP (2006). Evolutionary aspects of diet, the omega- 6 omega-3 ratio and genetic variation: nutritional implications for chronic diseases. Biomed Pharma 60: 502-507.

27. Arunkumar S \& Muthuselvam M (2009). Analysis of phytochemical constituents and antimicrobial activities of Aloe vera L. against clinical pathogens. World $J$ Agri Sci 5(5): 572-576. 